\title{
Factors associated with the incidence of pressure ulcer during hospital stay
}

\author{
Fatores associados à incidência de úlcera por pressão durante a internação hospitalar \\ Factores asociados con la incidencia de úlcera por presión durante la estancia hospitalaria
}

Fernanda Penido Matozinhos ${ }^{1}$, Gustavo Velasquez-Melendez ${ }^{1}$, Sabrina Daros Tiensoli ${ }^{1}$, Alexandra Dias Moreira ${ }^{1}$, Flávia Sampaio Latini Gomes ${ }^{1}$

How to cite this article:

Matozinhos FP, Velasquez-Melendez G, Tiensoli SD, Moreira AD, Gomes FSL. Factors associated with the incidence of pressure ulcer during hospital stay. Rev Esc Enferm USP. 2017;51:e03223. DOI: http://dx.doi.org/10.1590/S1980-220X2016015803223

1 Universidade Federal de Minas Gerais, Escola de Enfermagem, Belo Horizonte, MG, Brazil.

\begin{abstract}
Objective: Estimating the incidence rate of pressure ulcers and verifying factors associated with this occurrence in a cohort of hospitalized patients. Method: This is a cohort study in which the considered outcome was the time until pressure ulcer occurrence. Estimated effect of the variables on the cumulative incidence ratio of the outcome was performed using the Cox proportional hazards model. Variable selection occurred via the Logrank hypothesis test. Results: The sample consisted of 442 adults, with 25 incidents of pressure ulcers. Patients with high scores on the Braden scale presented a higher risk of pressure ulcer incidence when compared to those classified into the low score category. Conclusion: These results reinforce the importance of using the Braden Scale to assist in identifying patients more likely to develop pressure ulcers.
\end{abstract}

DESCRIPTORS

Pressure Ulcer; Inpatients; Incidence; Survival Analysis; Nursing Care. 


\section{INTRODUCTION}

Pressure ulcers (PU) represent an important challenge in relation to the care provided to hospitalized patients, since they significantly impact morbidity/mortality and quality of life ${ }^{(1-2)}$. In addition, treating these wounds is often prolonged and costly $y^{(2-3)}$, and their occurrence is an important indicator of the quality of care.

Most patients who develop PU have poor physical or mental health conditions ${ }^{(4)}$, or other comorbidities, revealing that these wounds have multifactorial etiology. They can have direct causes such as pressure and friction in tissue, loss of sensation or immobility; and indirect causes such as: long hospital stay, old age, presence of neurological disorders, cancer or other comorbidities, the use of vasoactive drugs, and malnutrition ${ }^{(4-7)}$.

Given the complexity of these factors, a high incidence of PU in several hospital sectors can be observed. A multicenter study conducted in hospitalization units in Brazil showed PU frequency in $17 \%$ of patients, most of which were affected by more than one lesion, and especially in the sacral, trochanteric, calcaneal, back and elbow regions ${ }^{(5)}$. This proportion can range from 29 to $53 \%$ in intensive care units ${ }^{(6,8)}$.

In this context, high PU frequencies demand early identification of patients with a high probability of developing wounds ${ }^{(9)}$. One way to measure this risk is to use the Braden Scale, which addresses intrinsic and extrinsic factors such as sensory perception, moisture, activity, mobility, nutrition, friction and shear ${ }^{(10)}$. This evaluation has shown to be valid for predicting wounds, thus allowing for implementation of preventive measures by the multidisciplinary team ${ }^{(10-11)}$.

To our knowledge, there are few longitudinal studies in Brazil that evaluate PU determinants and their incidence in patients hospitalized in specific sectors. Faced with this reality, it is necessary to understand factors associated with PU development in the medical clinic, where patients stay longer than in acute care clinics. We believe that studies focused on this theme can optimize planning of preventive measures in the care offered by nursing professionals and promote reduction of pressure ulcers.

Therefore, this study proposes to estimate PU incidence rate in a cohort of hospitalized patients in the medical clinic and to verify the factors associated with its occurrence.

\section{METHOD}

This is a prospective cohort study. The participants were recruited at a university hospital integrated to the Brazilian Unified Health System (Sistema Unico de Saúde - SUS), in the city of Belo Horizonte, Minas Gerais state. The population consisted of all adult patients hospitalized in the 67 beds of the Inpatient Unit. The convenience sample consisted of an open cohort of all hospitalized patients from May to November 2012.

Data collection was performed during six months by a team of two properly trained nurses in the hospital under study and one undergraduate nursing student through a structured questionnaire with questions related to sociodemographic and clinical aspects recorded in the patients' medical chart and by direct observation.
It should be emphasized that the field supervision and training the interviewers for data collection was carried out by professors and researching nurses. This training consisted of a theoretical and a practical phase. The questionnaire was previously tested at the beginning of the data collection, including by the Kappa test for agreement of Braden Scale's applicability among the interviewers.

PU was defined as "a wound on the skin or underlying tissue, usually located on a prominent bone as a result of pressure in the area or pressure in combination with shearing," friction or the combination of the three forces ${ }^{(12)}$.

The outcome or dependent variable was time until PU appearance. The event variable was $\mathrm{PU}$ appearance, which assumed a value of 1 if the event occurred, and 0 if it was censored (observation losses during follow-up or hospital discharge). A comparative analysis was performed between the losses and the final sample, and no significant differences were found between them.

The method used to calculate estimates of PU incidence was incidence density, in which the denominator was number of patients-day, as considered from the $1^{\text {st }}$ day of hospitalization of each patient in the hospitalization unit until PU appearance. The cohort was followed up for a minimum of 10 hospitalization days and for a maximum of 80 days.

Independent variables included in this study were: age group (adults - between 18 and 60 years and older adults individuals over 60 years of age); gender (male or female); self-reported skin color (white or brown + black); smoking (non-smoking, smoking or former smoker); Braden Scale scores and Body Mass Index (BMI).

The Braden Scale maximum score is 23 and the minimum score is 6 , with risk classification ranges considered as: $>18$, no risk; 15 to 18 , mild risk; 13 to 14 , moderate risk; 10 to 12 , high risk; and below or equal to 9 , very high risk ${ }^{(13)}$. In this study, the original Braden Scale score was considered, according to the validated values, but also considering the median of the variable. Thus, it was later opted to combine the classification categories into low risk (13 to 18 or more) and high risk (lower than 13).

BMI was calculated and categorized according to the recommendation by the World Health Organization $(\mathrm{WHO})^{(14)}$. This data was used to evaluate the nutritional status of hospitalized patients, considering patients as: malnourished with BMI < 18.5; eutrophic with $\mathrm{BMI} \geq 18.5$ and $<25$; and overweight with $\mathrm{BMI} \geq 25 \mathrm{~kg} / \mathrm{m}^{2}$.

Descriptive analysis of the categorical variables was presented as absolute means and percentage frequency, and continuous variables as median and interquartile range (IQR), due to the absence of symmetrical distribution.

Non-parametric estimates were obtained using the KaplanMeier (KM) survival analysis technique in order to calculate the incidence density of PU (univariate analysis), and the Logrank test for comparison of cumulative incidence curves.

A multivariate model of factors associated with $\mathrm{PU}$ incidence was constructed using the Cox regression technique, considering Hazard Ratio (HR) and 95\% confidence intervals as association measures. Previous selection of potential confounders was established considering values of $\mathrm{p}<0.20$; 
however, only the variables that obtained a level of significance $\mathrm{p}<0.05$ were kept in the final model. Statistical techniques were performed using the Statistical Software for Professionals, Stata, version 14.0.

The study was approved by the Research Ethics Committee of the Universidade Federal de Minas Gerais (Opinion number 02297412.1.0000.5149). Patients or caregivers were requested for approval to participate in the study, reading and signing of the Informed Consent Term. The study followed the regulations described in Resolution 466/2012 of the National Health Council.

\section{RESULTS}

The sample consisted of 442 adults and the median length of hospital stay was 22 days (IQR $=16-35)$. Twentyfive (25) incident cases of PU were recorded, and the number of patient-days was 10,324 . Thus, incidence density was $2.42 / 1,000$ people-day $(95 \% \mathrm{CI}=1.63-3.58)$.

Variable description and PU incidence in the sample are shown in Table 1. It should be noted that the total number of patients may vary due to the different rates of missing responses for the studied variables.

We found that the median BMI was $23.44 \mathrm{~kg} / \mathrm{m}^{2}$ (IQR $=20.76-27.34)$, with a predominance of individuals in the age group between 18 and 60 years (275 or $62.22 \%$ ), female (243 or $54.98 \%$ ), with brown and black skin color (223 or $51.15 \%$ ), non-smokers (225 or $51.96 \%$ ), without risk according to original Braden Scale scores (265 or 59.95\%), and eutrophic (179 or 49.04\%).

Table 1 - Description of variables and PU incidence in the sample - Belo Horizonte, Minas Gerais, Brazil, 2012

\begin{tabular}{lcc}
\hline \multirow{2}{*}{ Variables } & Total sample & Pressure ulcers \\
\cline { 2 - 3 } Age group (years) & $\mathbf{n}^{*}(\%)$ & $\mathrm{n}^{*}$ \\
$18-60$ & $442(100.00)$ & \\
$>60$ & $275(62.22)$ & 14 \\
\hline Gender & $167(37.78)$ & 11 \\
Male & $442(100.00)$ & \\
Female & $199(45.02)$ & 18 \\
\hline Skin color & $243(54.98)$ & 7 \\
White & $436(100.00)$ & \\
Brown + Black & $213(48.85)$ & 16 \\
\hline Smoking & $223(51.15)$ & 9 \\
No & $433(100.00)$ & \\
Yes & $225(51.96)$ & 11 \\
Former smoker & $55(12.70)$ & 4 \\
\hline Braden Scale original scores & $442(100.00)$ & 10 \\
No risk & $265(59.95 \%)$ & 2 \\
Mild risk & $83(18.78 \%)$ & 3 \\
Moderate risk & $40(9.05 \%)$ & 4 \\
High risk & $43(9.73 \%)$ & 15 \\
Very high risk & $11(2.49 \%)$ & 1 \\
\hline & & continued... \\
\hline & & \\
\hline & & \\
\hline & & \\
\hline
\end{tabular}

\begin{tabular}{lcc}
...continuation & & \\
\hline \multirow{2}{*}{ Variables } & Total sample & Pressure ulcers \\
\cline { 2 - 3 } & $\mathbf{n} *(\%)$ & $\mathbf{n}^{*}$ \\
\hline Braden Scale scores & $442(100.00)$ & \\
Low risk (> 18 to 13$)$ & $388(87.78)$ & 9 \\
High risk $(12$ and $\leq 9)$ & $54(12.22)$ & 16 \\
\hline Body Mass Index $\left(\mathrm{Kg} / \mathbf{m}^{2}\right)$ & $365(100.00)$ & \\
Malnourished $(<18.5)$ & $44(12.05)$ & 2 \\
Eutrophic $(\geq 18.5$ and $<25)$ & $179(49.04)$ & 12 \\
\hline
\end{tabular}

Note: *Number of individuals.

Source: Authors' own elaboration.

Table 2 shows the incidence densities of the outcome variable according to the independent variables of the study.

Table 2 - Incidence densities of the outcome variable, according to independent variables of the study - Belo Horizonte, Minas Gerais, Brazil, 2012

\begin{tabular}{|c|c|}
\hline \multirow{2}{*}{ Variables } & Incidence (x1000 people-day) \\
\hline & and $(95 \% \mathrm{Cl} *)$ \\
\hline \multicolumn{2}{|c|}{ Age group (years) } \\
\hline $18-60$ & $2.27(1.34-3.83)$ \\
\hline$>60$ & $2.64(1.46-4.77)$ \\
\hline \multicolumn{2}{|l|}{ Gender } \\
\hline Male & $3.26(2.05-5.18)$ \\
\hline Female & $1.45(0.69-3.05)$ \\
\hline \multicolumn{2}{|l|}{ Skin color } \\
\hline White & $3.36(2.06-5.49)$ \\
\hline Brown + Black & $1.65(0.85-3.17)$ \\
\hline \multicolumn{2}{|l|}{ Smoking } \\
\hline No & $2.15(1.19-3.89)$ \\
\hline Yes & $2.99(1.12-7.98)$ \\
\hline Former smoker & $2.73(1.46-5.07)$ \\
\hline \multicolumn{2}{|c|}{ Braden Scale original scores } \\
\hline No risk & $0.38(0.09-1.51)$ \\
\hline Mild risk & $1.28(0.41-3.96)$ \\
\hline Moderate risk & $3.27(1.23-8.72)$ \\
\hline High risk & $9.62(5.80-16.00)$ \\
\hline Very high risk & $4.38(0.62-31.00)$ \\
\hline \multicolumn{2}{|c|}{ Braden Scale scores } \\
\hline Low risk & $1.06(0.55-2.04)$ \\
\hline High risk & $8.58(5.26-14.01)$ \\
\hline \multicolumn{2}{|c|}{ Body Mass Index } \\
\hline Malnourished & $1.79(0.44-7.17)$ \\
\hline Eutrophic & $2.79(1.58-4.91)$ \\
\hline Overweight & $0.89(0.28-2.78)$ \\
\hline
\end{tabular}

Note: *95\% confidence intervals.

Source: Authors' own elaboration.

Figure 1 shows the accumulated risk function for PU, which estimates the risk of developing PU during a specific period of time for the total population.

The proportion of accumulated PU risk in individuals older than 60 years of age was not statistically higher when compared to those aged 18 to 60 years. A statistical significance was also not found in comparing patients regarding gender, skin color, smoking or nutritional status.

Figure 2 shows the accumulated risk functions for PU 
according to the Braden Scale score categories. A statistical significance $(p<0.01)$ was observed for a higher proportion of accumulated risk in high risk individuals (score below 13) in relation to the other category (low risk - score of 13 to 18 or higher). A similar situation was found with the original Braden Scale score categories ( $\mathrm{p}<0.01)$ (figure not shown).

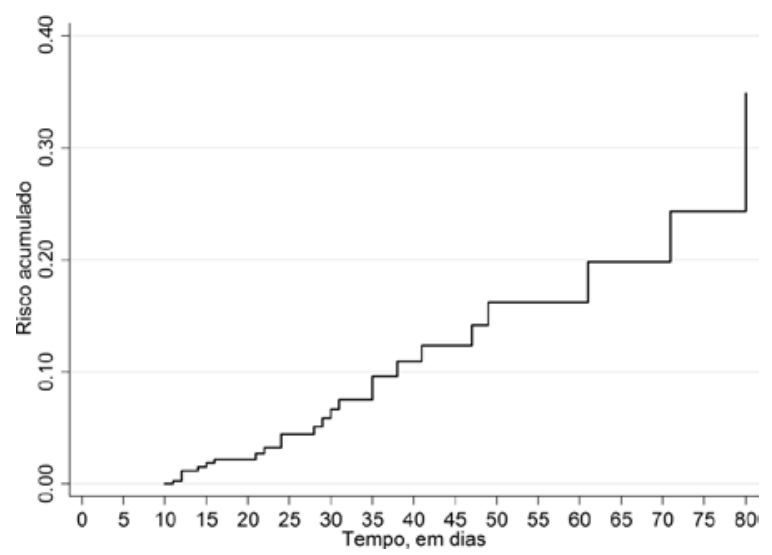

Source: Authors' own elaboration

Figure 1 - Proportion of accumulated PU risk - Belo Horizonte, Minas Gerais, Brazil, 2012

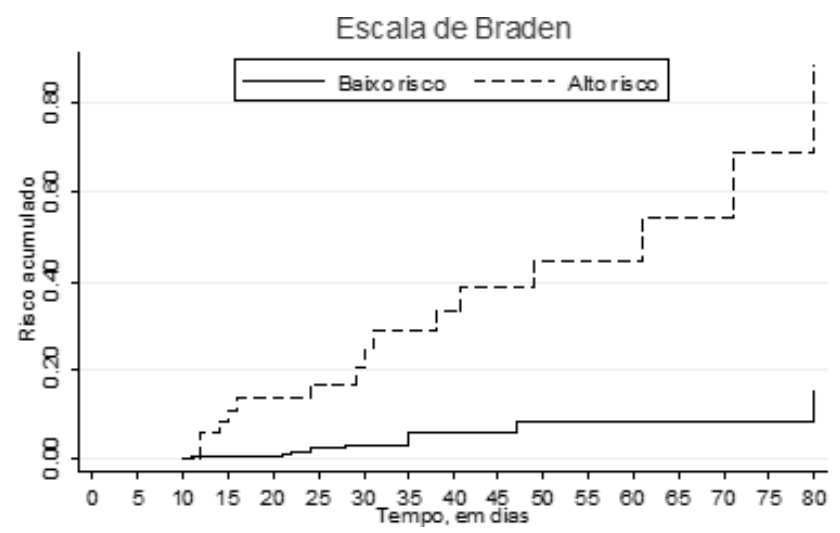

Source: Authors' own elaboration

Figure 2 - Proportion of accumulated PU risk according to the categories of grouped Braden Scale scores - Belo Horizonte, Minas Gerais, Brazil, 2012

Table 3 shows Hazard Ratio (HR) and 95\% CI for PU. No statistically significant differences were observed in relation to PU incidence in hospitalized patients, except for some of the Braden Scale categories $(\mathrm{p}<0.001)$.

Table 3 - Hazard Ratio and 95\%Cl for pressure ulcers - Belo Horizonte, Minas Gerais, Brazil, 2012

\begin{tabular}{|c|c|c|}
\hline \multirow{2}{*}{ Variables } & Gross $\mathrm{HR}^{*}$ & \multirow{2}{*}{ Adjusted $\mathrm{HR}^{*}(95 \% \mathrm{Cl}+)$} \\
\hline & $(95 \% \mathrm{Cl}+)$ & \\
\hline \multicolumn{3}{|l|}{ Age group (years) } \\
\hline $18-60$ & 1 & \multirow{2}{*}{-} \\
\hline$>60$ & $1.16(0.52-2.56)$ & \\
\hline \multicolumn{3}{|l|}{ Gender } \\
\hline Male & 1 & 1 \\
\hline Female & $0.44(0.18-1.06)$ & $0.66(0.27-1.61)$ \\
\hline \multicolumn{3}{|l|}{ Skin color } \\
\hline White & 1 & 1 \\
\hline Brown + Black & $0.49(0.21-1.11)$ & $0.52(0.22-1.18)$ \\
\hline \multicolumn{3}{|l|}{ Smoking } \\
\hline No & 1 & \\
\hline Yes & $1.38(0.44-4.36)$ & - \\
\hline Former smoker & $1.26(0.53-2.97)$ & \\
\hline \multicolumn{3}{|c|}{ Braden Scale original scores } \\
\hline No risk & 1 & 1 \\
\hline Mild risk & $0.29(0.05-1.77)$ & $2.92(0.48-17.70)$ \\
\hline Moderate risk & $0.12(0.02-0.63)$ & $7.08(1.28-9.21)$ \\
\hline High risk & $0.04(0.00-0.17)$ & $17.36(3.83-78.64)$ \\
\hline Very high risk & $0.08(0.00-0.95)$ & $10.85(0.97-12.13)$ \\
\hline \multicolumn{3}{|c|}{ Braden Scale scores } \\
\hline Low risk & 1 & 1 \\
\hline High risk & $8.07(3.56-18.27)$ & $6.31(2.73-14.58)$ \\
\hline \multicolumn{3}{|l|}{ Body Mass Index } \\
\hline Malnourished & 1 & \\
\hline Eutrophic & $1.55(0.34-6.95)$ & - \\
\hline Overweight & $0.50(0.08-2.99)$ & \\
\hline
\end{tabular}

Notes: *Hazard Ratio; † 95\% confidence intervals.

Source: Authors' own elaboration. 


\section{DISCUSSION}

The present study revealed a $\mathrm{PU}$ incidence rate in hospitalized patients of $2.42 / 1000$ people-day $(95 \% \mathrm{CI}=1.63-$ 3.58). Another finding of this study shows that sociodemographic and clinical factors in hospitalized patients were not shown to be associated with PU incidence in the adjusted multivariate model. However, patients who were classified as being at higher risk on the Braden Scale presented more than six times the risk of PU incidence when compared to those classified in the low risk category.

A study of PU incidence and prevalence shows how common these wounds are ${ }^{(2)}$. PU incidence rates in countries around the world vary from $1.9 \%$ to $71.6 \%$, and the incidence rate in the context of long-term care units (for example in medical clinic units) reaches $6.6 \%(2,15)$.

Despite incidence rate or incidence density representing more consistent analysis of the incidence data, few studies related to $\mathrm{PU}$ are found in the national literature. In this study, we found that 2.42/1,000 patients-day hospitalized in the medical clinic unit developed PU. Another study on PU incidence density in institutionalized elderly people in the south of Minas Gerais found 5.7 elderly people with wounds at every 1,000 days of hospitalization ${ }^{(16)}$. A second study carried out in the medical clinic units of two public hospitals in Bahia showed PU incidence densities of 70/1,000 peopledays and 32/1,000 people-days, respectively ${ }^{(17)}$.

It is worth noting that PU high incidence has been observed in environments where organizational strategies for PU prevention are inadequate or non-existent ${ }^{(18)}$.

Regarding the independent variable of smoking, no statistically significant differences were found between smokers and non-smokers, similar to a study carried out in the city of São Paulo ${ }^{(19)}$. It is known that despite these results, smoking impairs the function of several cells, compromises tissue oxygenation and has effects on the physiology of chronic wounds, in addition to prolonging the treatment period ${ }^{(20)}$.

Other studies have corroborated the results of the present study as they did not find significant differences in PU development between genders ${ }^{(21-22)}$. However, demographic data show that women have a higher life expectancy than men (78.6 and 71.3 years, respectively) ${ }^{(23)}$, so therefore they live longer periods with disabilities and chronic diseases, which could increase PU incidence in females ${ }^{(21)}$.

Regarding the association between age and PU, some authors affirm that age group over 60 years is a risk factor for developing PU due to changes in skin and subcutaneous tissue inherent to aging ${ }^{(21,24-25)}$. Such lesions can be considered mortality predictors in advanced-aged individuals, regardless of other risk factors ${ }^{(26)}$. Despite no significant association being found in this study between age group and PU, it is important to emphasize the importance of multidisciplinary practice in preventing and treating PU in the elderly, especially those in situations of fragility, immobility and malnutrition. Reducing PU incidence related to population aging is a challenge for professionals and the health system, where multiprofessional teams' continuing education is fundamental to achieving qualified care.
Although the patient's nutritional status is considered a potential risk factor for PU development ${ }^{(24-25,27)}$, no significant association was demonstrated in this study. Evidence that dietary interventions and dietary supplements can effectively prevent or accelerate the healing process of $\mathrm{PU}$ are conflicting and require more scientific research ${ }^{(27)}$. Nonetheless, performance by members of the multidisciplinary team such as nursing and nutrition professionals is essential to reach an appropriate BMI, thus preventing metabolic disturbances leading to the onset of PU and other health problems, which in most cases can worsen the patients' general health status.

The highest risk category of the Braden Scale was associated with PU development. This result corroborates the findings of other studies ${ }^{(11,28)}$. A previous study showed that the scale is an adequate tool for predicting risk for PU appearance $^{(11)}$. One study also revealed high sensitivity in wound evaluation, and the instrument is considered appropriate for screening and important for clinical practice ${ }^{(10)}$.

A statistically significant association was observed between risk and the presence of PU in two hospital units, showing evidence that there was a higher percentage of patients with high risk in the group of patients with PU when compared to the group without PU in both units. In performing a logistic regression analysis to verify the influence of the Braden Scale score on PU presence, it was observed that patients in the surgical clinic with high risk are about 10 times more likely to develop PU when compared to low-risk and moderate risk patients. On the other hand, high risk patients in the Intensive Care Unit are 25.5 times more likely to develop PU than low and moderate risk patients ${ }^{(28)}$.

Differences in the risk of developing PU between studies can be explained among other specificities of the methods used, by the place of study. After all, it is known that PU incidence in acute care units is higher than in those of longterm care.

These results show that the systematic use of the Braden Scale is an important strategy in treating patients, and the use of this scale should be understood as a parameter of good nursing practice which can contribute to improving the process indicator for PU prevention ${ }^{(13)}$.

In addition, nursing staff dynamics in health institutions should be ensured in a way that not only allows for using the scale, but also for implementing preventive measures for PU development such as the periodic change of the patient's position, use of necessary supplies and equipment such as appropriate mattresses, and multidisciplinary team involvement in providing specific care to patients at greater risk.

Studies such as this contribute to reinforcing this care among the multidisciplinary team. Although the risk of PU has limits related to factors identified here, improvement in the quality of care is a factor that must be taken into account aiming at patient safety.

Finally, it is important to consider some limitations of this study, among them the reduced sample size which may have influenced the lack of statistical significance in some of the presented results. However, it should be emphasized that the population served in public university hospitals may 
have similar sociodemographic characteristics, which makes it difficult to identify differences between groups.

\section{CONCLUSION}

Hospitalized patients with high values on the Braden scale showed higher PU incidence when compared to those with low values. Socio-demographic and clinical factors in the studied scenario did not show significant differences in PU incidence. This fact reinforces the importance of using this scale to aid in identifying patients with a higher probability of developing PU.Thus, these results may alert health institutions to put priority on its use by providing the necessary conditions for its implementation through training and continuing education in order to optimize patient care and quality of life.

\section{RESUMO}

Objetivo: Estimar a taxa de incidência de úlcera por pressão e verificar fatores associados a essa ocorrência em uma coorte de pacientes hospitalizados. Método: Trata-se de estudo de coorte no qual o desfecho foi a ocorrência da úlcera por pressão. A estimativa do efeito das variáveis para a proporção de incidência acumulada do desfecho foi realizada utilizando o modelo de riscos proporcionais de Cox. A seleção das variáveis ocorreu por meio do teste de hipóteses Logrank. Resultados: A amostra foi composta de 442 adultos, com 25 casos incidentes de úlcera por pressão. Pacientes com altos escores na escala de Braden apresentaram maior risco de incidência de úlcera por pressão quando comparados com aqueles classificados na categoria de baixo escore. Conclusão: Os resultados reforçam a importância do uso da Escala de Braden para auxiliar na identificação dos pacientes com maior probabilidade de desenvolver úlcera por pressão. DESCRITORES: Úlcera por Pressão; Pacientes Internados; Incidência; Análise de Sobrevida; Cuidados de Enfermagem.

\section{RESUMEN}

Objetivo: Estimar la tasa de incidencia de úlcera por presión y verificar factores asociados a esa ocurrencia en una cohorte de pacientes hospitalizados. Método: Se trata de estudio de cohorte en el que el resultado fue la ocurrencia de la úlcera por presión. La estimación del efecto de las variables para la proporción de incidencia acumulada del resultado fue realizada utilizando el modelo de riesgos proporcionales de Cox. La selección de las variables ocurrió mediante el test de hipótesis de Log-Rank. Resultados: La muestra estuvo compuesta de 442 adultos, con 25 casos incidentes de úlcera por presión. Pacientes con altos puntajes en la escala de Braden presentaron mayor riesgo de incidencia de úlcera por presión cuando comparados con aquellos clasificados en la categoría de bajo escore. Conclusión: Los resultados refuerzan la importancia del empleo de la Escala de Braden para auxiliar la identificación de los pacientes con mayor probabilidad de desarrollar úlcera por presión.

\section{DESCRIPTORES}

Úlcera por Presión; Pacientes Internos; Incidencia; Análisis de Supervivencia; Atención de Enfermería.

\section{REFERENCES}

1. Gorecki C, Nixon J, Madill A, Firth J, Brown JM. What influences the impact of pressure ulcers on health-related quality of life? A qualitative patient-focused exploration of contributory factors. J Tissue Viability. 2012;21(1):3-12.

2. Moore ZE, Webster J, Samuriwo R. Wound-care teams for preventing and treating pressure ulcers. Cochrane Database Syst Rev. 2015;(9):CD011011.

3. Chou R, Dana T, Bougatsos C, Blazinal, Starmer A, Reitel K, et al. Pressure ulcer risk assessment and prevention: comparative effectiveness [Internet]. Rockville: Agency for Healthcare Research and Quality; 2013 [cited 2016 Apr 25]. Available from http://www.ncbi.nlm.nih. gov/books/NBK143579/

4. Bhattacharya S, Mishra RK. Pressure ulcers: current understanding and newer modalities of treatment. Indian J Plast Surg. 2015;48(1):4-16.

5. Brito PA, Generoso SV, Correia MITD. Prevalence of pressure ulcers in hospitals in Brazil and association with nutritional status: a multicenter, cross-sectional study. Nutrition. 2013;29(4):646-9.

6. Costa ACO, Pinho CPS, Santos ADA, Nascimento ACS. Pressure ulcer: incidence and demographic, clinical and nutrition factors associated in intensive care unit patients. Nutr Hosp. 2015;32(5):2242-52.

7. Perrone F, Paiva AA, Souza LMI, Faria CS, Paese MCS, Aguilar-Nascimento JE, et al. Estado nutricional e capacidade funcional na úlcera por pressão em pacientes hospitalizados. Rev Nutr (Campinas). 2011;24(3):431-8.

8. Bezerra SMG, Pereira LC, Luz MHBA, Santana WS. Incidência de úlceras por pressão em uma Unidade de Terapia Intensiva de um hospital público. Rev Enferm UFPI. 2014;2(4):21-7.

9. Qaseem A, Mir TP, Starker M, Denberg T. Risk assessment and prevention of pressure ulcers: a clinical practice guideline from the American College of Physicians. Ann Intern Med. 2015;162(5):359-69.

10. Borghardt AT, Prado TN, Araújo TM, Rogenski NMB, Bringuente MEO. Evaluation of the pressure ulcers risk scales with critically ill patients: a prospective cohort study. Rev Latino Am Enfermagem. 2015;23(1):28-35.

11. Miller N, Frankenfield D, Lehman E, Maguire M, Schirm V. Predicting pressure ulcer development in clinical practice: evaluation of Braden Scale Scores and nutrition parameters. J Wound Ostomy Continence Nurs. 2016;43(2):133-9.

12. National Pressure Ulcer Advisory Panel; European Pressure Ulcer Advisory Panel and Pan Pacific Pressure Injury Alliance. Prevention and treatment of pressure ulcers: quick reference guide. Cambridge Media: Osborne Park; 2014. 
13. Brasil. Ministério da Saúde; Agência Nacional de Vigilância Sanitária. Programa Nacional de Segurança do Paciente. Protocolo para Prevenção de Úlcera por Pressão. Brasília: Fiocruz; 2013.

14. World Health Organization. Physical status: the use and interpretation of anthropometry. Geneva: WHO; 1995.

15. Moore Z, Johanssen E, Van Etten M. A review of PU prevalence and incidence across Scandinavia, Iceland and Ireland (Part I). J Wound Care. 2013;22(7):361-8.

16. Souza DMST, Santos VLCG. Risk factors for pressure ulcer development in institutionalized elderly. Rev Latino Am Enfermagem. 2007;15(5):958-64.

17. Anselmi ML, Peduzzi M, França Júnior I. Incidência de úlcera por pressão e ações de enfermagem. Acta Paul Enferm, 2009;22(3):257-64.

18. Igarashi A, Yamamoto-Mitani N, Gushiken Y, Takai Y, Tanaka M, Okamoto Y. Prevalence and incidence of pressure ulcers in Japanese longterm-care hospitals. Arch Gerontol Geriatr. 2013;56(1):220-6.

19. Campanili TC, Gonçalves F, Santos VLCG, Strazzieri-Pulido KC, Thomaz PBM, Nogueira PC. Incidence of pressure ulcers in cardiopulmonary intensive care unit patients. Rev Esc Enferm USP. 2015;49(n.spe):7-13.

20. McDaniel JC, Browning KK. Smoking, chronic wound healing, and implications forevidence-based practice. J Wound Ostomy Continence Nurs. 2014;41(5):415-23.

21. Freitas JPC, Alberti LR. Application of the Braden Scale in the home setting: incidence and factors associated with pressure ulcers. Acta Paul Enferm. 2013;26(6): 515-21.

22. Soares DAS, Vendramin FS, Pereira LMD, Proença PK, Marques MM. Analysis of the incidence of pressure ulcers at Hospital Metropolitano de Urgência e Emergência in Ananindeua, PA. Rev Bras Cir Plást. 2011;26(4):578-81.

23. Brasil. Ministério do Planejamento, Orçamento e Gestão; Instituto Brasileiro de Geografia e Estatística. Tábua completa de mortalidade para o Brasil-2013: breve análise da mortalidade nos períodos 20122013 e 1980 2013. Rio de Janeiro: IBGE; 2014.

24. Horn SD, Barrett RS, Fife CE, Thomson B. A predictive model for pressure ulcer outcome: the Wound Healing Index. Adv Skin Wound Care. 2015;28(12):560-72.

25. Gould L, Abadir P, Brem H, Carter M, Conner-Kerr T, Davidson J, et al. Chronic wound repair and healing in older adults: current status and future research. J Am Geriatr Soc. 2015;63(3):427-38.

26. Gené BJ, Borràs SA, Contel SJC, Terén CA, González LC, Ramírez EL, et al. Predictors of mortality among elderly dependent home care patients. BMC Health Serv Res. 2013;13:316.

27. Meehan A, Loose C, Bell J, Partridge J, Nelson J, Goates S. Health system quality improvement: impact of prompt nutrition care on patient outcomes and health care costs. J Nurs Care Qual. 2016;31(3):217-23.

28. Rogenski NMB, Kurcgant P. The incidence of pressure ulcers after the implementation of a prevention protocol. Rev Latino Am Enfermagem. 2012;20(2): 333-9. 